\title{
Optimization of Student Loyalty through Rewards and Students' Satisfaction as Intervening Variables
}

\author{
Durahman Marpaung ${ }^{1}$, Prianda Pebri ${ }^{2}$, Nirmalasari $^{3}$, Srie Hartati ${ }^{4}$, Nasib $^{5}$ \\ ${ }^{1,2}$ STIE Muhammadiyah Asahan, Indonesia \\ ${ }^{3,4}$ Politeknik Unggul LP3M, Indonesia \\ ${ }^{5}$ STIE Mahkota Tricom Unggul, Indonesia \\ prianda.pebri89@gmail.com
}

\begin{abstract}
STIE Muhammadiyah Asahan is a private university under the supervision of Regional 1 Education Service Institution (LL Dikti Wilayah 1). This study aims to determine the Optimization of Student Loyalty through Rewards and Students' Satisfaction as Intervening Variables. The research approach used in this research is quantitative. Data obtained by distributing questionnaires with a Likert scale. The questionnaire is arranged based on indicators of reward, satisfaction and loyalty. The target population in this study are 71 students for the 2017-2018 academic year. The sampling technique uses saturated samples. So that 71 respondents are selected to be the sample. Data analysis uses path analysis to determine the direct and indirect effect of the reward variable on student loyalty through student satisfaction. The results of the research that can be drawn 1) Rewards have a significant effect on student satisfaction at STIE Muhammadiyah Asahan. 2) Reward has no effect on student loyalty at STIE Muhammadiyah Asahan. 3) Student satisfaction has a significant effect on student loyalty at STIE Muhammadiyah Asahan.. 4) Reward has a significant effect on student loyalty through student satisfaction at STIE Muhammadiyah Asahan.
\end{abstract}

Keywords

student loyalty, intervening variables, rewards and students' satisfaction

\section{Introduction}

STIE Muhammadiyah Asahan is a private university under the supervision of Regional 1 Education Service Institution (LL Dikti Wilayah 1). So far, the main financial support for campus operational expenses is from students' fund. To increase the number of students, University involves active students in marketing. Here is the data on new student admissions in the last 3 years:

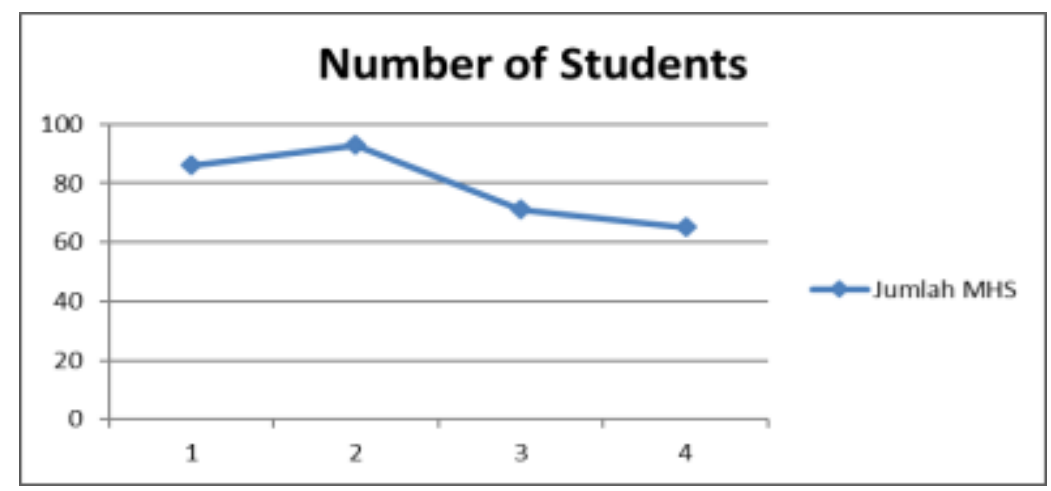

Figure 1. The Data of New Students Admission 
Based on the seeing the existing phenomena, especially in giving rewards, it cannot be separated from the sense of satisfaction of the students at STIE Muhammadiyah Asahan. Because this feeling of satisfaction will have an impact on student loyalty to join the member get member program (Purwati, 2019). It is the reason that this research is very necessary specifically for management in evaluating the activities of the member get member in increasing the number of prospective students at STIE Muhammadiyah Asahan.

Figure above, the trend of student acceptance is decreasing. If it continues, it gives a risk, especially in the ability to finance operating expenses. There are some efforts to increase the number of new students is always executed to be able to survive in the midst of competition with other universities. The strategy of member get member was introduced in 2017 to students for the first time by giving a reward of Rp. 750,000 to students who managed to invite new students to study at STIE Muhammadiyah Asahan.

In 2018 the management made a different policy where a reward becomes IDR 350,000 plus giving free travel tickets abroad (Singapore-Malaysia) for students who are able to invite at least 7 students to study at STIE Muhammadiyah Asahan. Furthermore, in 2019 the management changed the reward provisions to IDR 500,000 for students who can invite new students to study at STIE Muhammadiyah Asahan.

\section{Review of Literature}

\subsection{Student Loyalty}

Students in private universities are indirectly consumers who have to be served well. One proof of student loyalty to their alma mater is by consistently to involve in program of member get member, to bring in other people to study at the same campus (Keller, 2012). Strong loyalty tends to make a student feel proud of the campus he has chosen. In addition, students will especially recommend to their relatives to study at the same campus (Amelia, 2018). Satisfied students are a manifestation of loyalty to higher education (Rinawati, 2016). As a student you can have a hidden sense of loyalty. This does not mean that students do not want to recommend friends or relatives to study at the same college, but at this time no friends or relatives can be invited to study on the grounds that they do not meet the need to study for college and so on (Griffin, 2010).

\subsection{Students Satisfaction}

Students want everything they expect from higher education to be realized. For any higher education institutions that continue to make improvements to make minimalize the gap between the expectations of students with existing services, in this situation, complaints can be avoided (Syakur, 2018). Learning was then developed by Keller into four components. The four components are attention, relevance, confidence and satisfaction (Nurjanah et al, 2020). Satisfied students will have good comfort during the lecturing process (Adlan, 2017). The expectations to the students are an increase in knowledge and skills, the opportunity to work at bona fide companies, the involvement in foreign student meetings, increase in English and so on (Harjanto, 2020). So that the evaluation of the services carried out by staff and lecturers to students is collected after final semester exam to provide feedback in the next semester (Iriyadi, 2020).

\subsection{Reward}

The efforts to involve students in the higher education competition era is chosen because of cost efficiency in the marketing department (Fatricia, 2015). The students are directly involved in the new student admission program by providing rewards if they 
succeed in bringing new students to study at higher education (Amelia, 2018). The award varies from financial and non-financial incentives (Noviandari, 2018). The students have the choices. As a leader, of course, he will optimize limited resources in the success of the new student admissions program (Yani, 2020).

\subsection{Theoretical Framework}

Higher education institutions rely fully on donations of education funds have to certainly increased the number of new students which is so important for them. It is not uncommon for new student admissions program to be successful to involve all unseparated parties such as staff, lecturers and students. The reward is expected to be able to encourage especially students to participate in member get member activities.

Like a consumer, students also hope to be satisfied to have education activities in higher education. Being satisfied or not become a classic problem for all universities. When the students are satisfied it is expected to reduce the level of students' complaints. So that student loyalty in helping management in increasing the number of new students can be carried out well.

Previous research studies stated that giving rewards to students for loyalty has a significant effect (Nahar, 2018)(Kusumawidjaya, 2020)(Anggraini, 2020). However, not all students want to be involved in the marketing activities as expected by leaders in universities or foundations. Satisfaction should be part of existing services. Satisfaction factor will be taken into account by students in participating in new student admission activities (Torii, 2019)(Priyono, 2018), but not always satisfaction can increase student loyalty (Ismanova, 2019).

To get a clear direction for this research, the authors formulate a theoretical framework as follows:

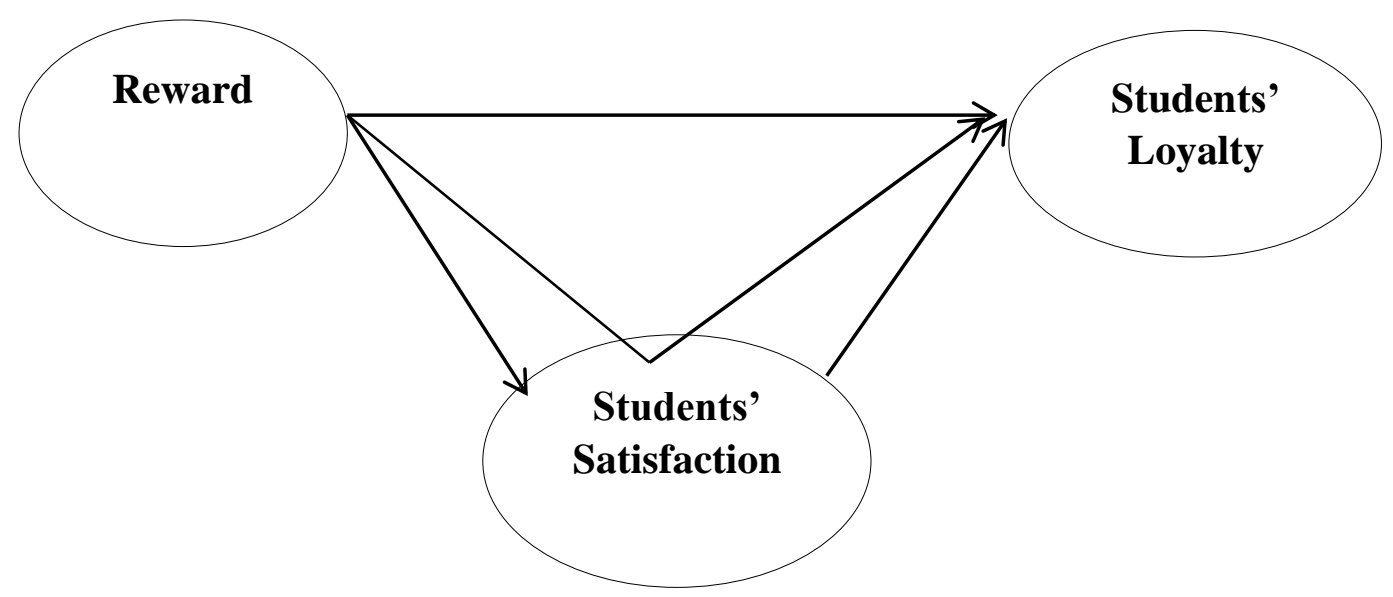

Figure 2. Theoretical Framework

\subsection{Hypothesis}

The research hypothesis are as follows:

H1: Reward has a significant effect on student satisfaction at STIE Muhammadiyah Asahan

H2: Reward has a significant effect on student loyalty at STIE Muhammadiyah Asahan

H3: Satisfaction has a significant effect on student loyalty at STIE Muhammadiyah Asahan

H4: Reward has a significant effect on student loyalty at STIE Muhammadiyah Asahan through student satisfaction 


\section{Research Methods}

The research approach used in this research is quantitative. Data obtained by distributing questionnaires with a Likert scale. The questionnaire is arranged based on indicators of reward, satisfaction and loyalty. The target population in this study are 71 students for the 2017-2018 academic year. The sampling technique uses saturated samples. So that 71 respondents are selected to be the sample. Data analysis uses path analysis to determine the direct and indirect effect of the reward variable on student loyalty through student satisfaction.

\section{Results and Discussion}

\subsection{Measurement Model Analysis (Outer Model) \\ a. Convergent Validity Test}

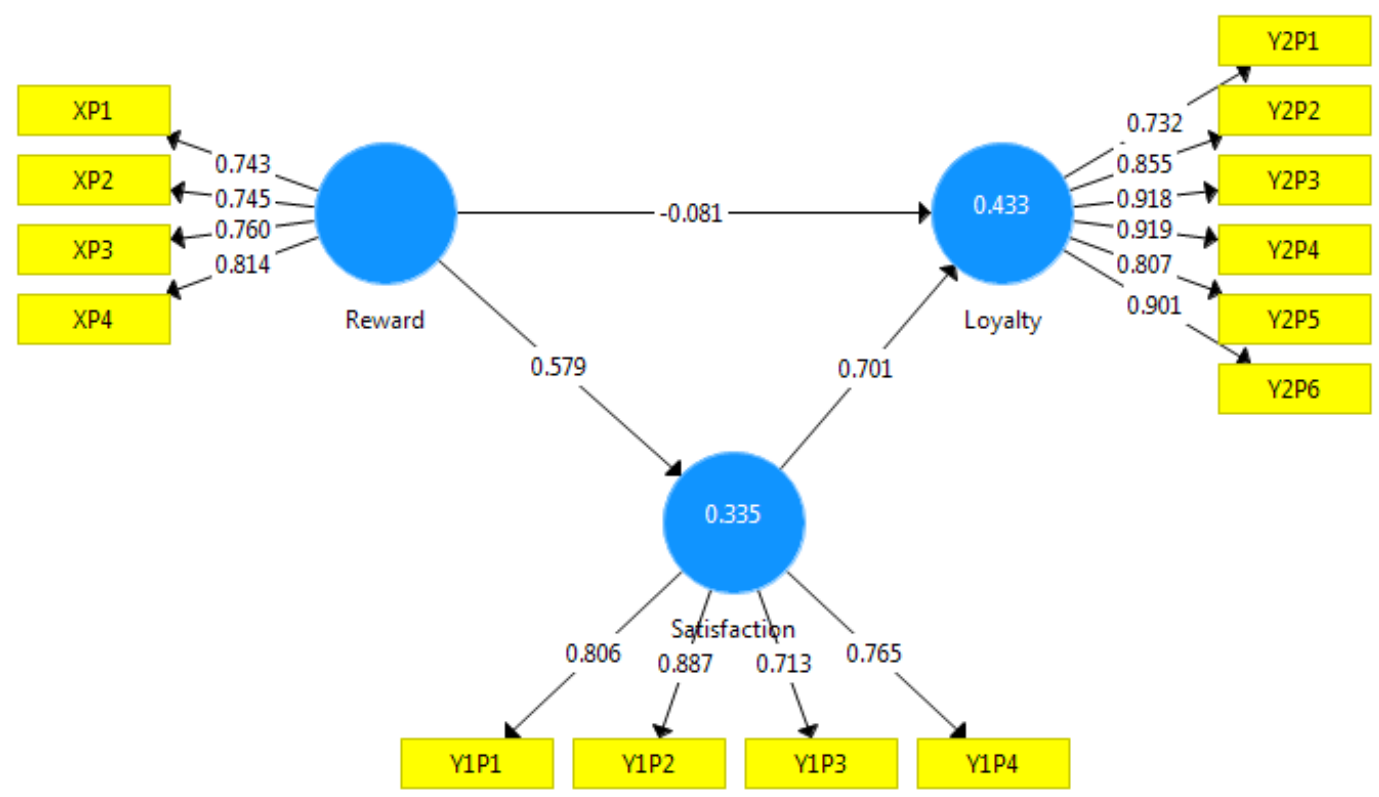

Figure 3. Result of Outer Model

Based on the picture above, all indicators in the model <0.7. So that it can be declared reliable for measuring the research variables. Then it can be used in the next analysis.

\section{b. Discriminant Validity Test}

The results of the determinant validity of the test data in this research are shown in the following table:

Tabel 1. Discriminant Validity

\begin{tabular}{|l|l|r|r|r|}
\hline Variable & Item & Loyalty & Satisfaction & Reward \\
\hline \multirow{4}{*}{ Reward } & X.P1 & 0.307 & 0.447 & 0.743 \\
\cline { 2 - 5 } & X.P2 & 0.199 & 0.373 & 0.745 \\
\cline { 2 - 5 } & X.P3 & 0.061 & 0.367 & 0.760 \\
\cline { 2 - 5 } & X.P4 & 0.340 & 0.535 & 0.814 \\
\hline
\end{tabular}




\begin{tabular}{|c|c|c|c|c|}
\hline \multirow{5}{*}{ Satisfaction } & Y1.P1 & 0.383 & 0.806 & 0.438 \\
\cline { 2 - 5 } & Y1.P2 & 0.552 & 0.887 & 0.568 \\
\cline { 2 - 5 } & Y1.P3 & 0.516 & 0.713 & 0.460 \\
\cline { 2 - 5 } Loyalty & Y1.P4 & 0.604 & 0.765 & 0.365 \\
\hline \multirow{5}{*}{} & Y2.P1 & 0.732 & 0.550 & 0.332 \\
\cline { 2 - 5 } & Y2.P2 & 0.855 & 0.477 & 0.224 \\
\cline { 2 - 5 } & Y2.P3 & 0.918 & 0.629 & 0.302 \\
\cline { 2 - 5 } & Y2.P4 & 0.919 & 0.638 & 0.319 \\
\cline { 2 - 5 } & Y2.P5 & 0.807 & 0.468 & 0.206 \\
\cline { 2 - 5 } & Y2.P6 & 0.901 & 0.569 & 0.268 \\
\hline
\end{tabular}

From table 1 above, the model has good discriminant validity if each of the loading indicator values of a latent variable is greater than the other correlated variables. The crossloading value in this research for each indicator is greater than the other latent variables. This shows that each variable has good discriminant validity.

\section{c. Construct Reliability Test}

The results of data processing show that:

Table 2. Construct Reliability

\begin{tabular}{|l|c|c|}
\hline Variabel & $\begin{array}{c}\text { Composite } \\
\text { Reliability }\end{array}$ & $\begin{array}{c}\text { Average Variance Extracted } \\
\text { (AVE) }\end{array}$ \\
\hline Reward & 0.850 & 0.587 \\
\hline Satisfaction & 0.872 & 0.632 \\
\hline Loyalty & 0.943 & 0.736 \\
\hline
\end{tabular}

Based on table 2, it shows that the average value is $>0.5$. Then the composite reliability value> 0.7 . So it can be concluded that the indicators in the study are able to measure well.

\subsection{Measurement Model Analysis (Inner Model)}

a. Coefficient of Determination (R2)

Table 3. R Square

\begin{tabular}{|l|r|r|}
\hline Variabel & $\begin{array}{l}\text { R } \\
\text { Square }\end{array}$ & $\begin{array}{l}\text { R Square } \\
\text { Adjusted }\end{array}$ \\
\hline Satisfaction & 0.335 & \\
\hline Loyalty & 0.433 & 0.325 \\
\hline
\end{tabular}

Based on the data from table 3, it is known that the $\mathrm{R}$ Square Adjusted value for student satisfaction variables is 0.325 or $32.5 \%$, while $67.5 \%$ as the remaining is influenced by other variables that are not the variables of this study. Then for the student loyalty variable, the value of $\mathrm{R}$ Square Adjusted is 0.416 or $41.6 \%$, while $58.4 \%$ as the remaining is influenced by other variables not included in this study. 


\section{b. Predictive Relevance $(\mathrm{Q} 2)$}

The value of Q2 has the same meaning as the coefficient of determination (RSquare). The value of Q- large Square (Q2) which is 0 indicates the model has Predictive relevance; but if a value (Q2) is less than 0 , it indicates that the model has less predictive relevance; or in other words, when it founds all the values of Q2 are higher, the model can be considered to fit the data better. Consideration of the value of Q2 can be done as follows $\mathrm{Q} 2=1-(1-\mathrm{R} 12)(1-\mathrm{R} 22) \ldots(1-\mathrm{Rn} 2)$

$\mathrm{Q} 2=1-(1-0.325) 1-0.416)$

$\mathrm{Q} 2=1-(0.675)(0.584)$

$\mathrm{Q} 2=1-0.394$

$\mathrm{Q} 2=0.606$

Based on these results, the Q2 value is 0.606 . So, it can be concluded that all variables in this study which are reward, student satisfaction and student loyalty contribute $60.6 \%$ to authenticity data. Then the remaining $39.4 \%$ needs to be developed apart from research variables.

\section{c. Effect Size (F2)}

Effect Size (F2) is to determine the benefit of the model. This is to determine whether the predictors of the variable have a weak, moderate, or strong influence at the structural level.

Table 4. Effect Tabel 6. Size (F2) test

\begin{tabular}{|l|r|r|}
\hline & Satisfaction & Loyalty \\
\hline Reward & 0.008 & \\
\hline Satisfaction & 0.577 & 0.503 \\
\hline Loyalty & & \\
\hline
\end{tabular}

Based on table 4, it shows that reward has a very weak effect on student satisfaction, then satisfaction has a moderate effect on student loyalty

\section{d. Hypothesis Test}

Table 5. Hypothesis Test

\begin{tabular}{|l|l|l|l|l|l|l|}
\hline Hypothesis & $\begin{array}{l}\text { Original } \\
\text { Sample } \\
\text { (O) }\end{array}$ & $\begin{array}{l}\text { Average } \\
(\mathrm{M})\end{array}$ & (STDEV) & $\begin{array}{l}\text { t } \\
\text { Statistics }\end{array}$ & $\begin{array}{l}\text { P } \\
\text { Value }\end{array}$ & Conclusion \\
\hline Reward-Satisfaction & 0.579 & 0.595 & 0.071 & 8.104 & 0.000 & Significant \\
\hline Reward-Loyalty & -0.008 & -0.085 & 0.114 & 0.711 & 0.477 & Insignificant \\
\hline Satisfaction-Loyalty & 0.701 & 0.720 & 0.103 & 6.781 & 0.000 & Significant \\
\hline $\begin{array}{l}\text { Reward-Satisfaction- } \\
\text { Loyalty }\end{array}$ & 0.406 & 0.429 & 0.087 & 4.659 & 0.000 & Significant \\
\hline
\end{tabular}

Based on the results of data analysis in table 5, it shows that reward has a significant effect on student satisfaction. The t-statistic value is 8.104> 1.99 with a significance of $0.000<0.005$. The results of this study are in line with research conducted by (Nasib, 2017) which states that giving rewards in the form of tuition discounts has an impact on increasing student satisfaction. Furthermore, giving the amount of this reward is at least of $20 \%$ discount on normal tuition fees (Martin, 2018). The requirements for getting the 
discount must be based on the rules that have been established and known by the (head) management and the foundation. Then, based on the descriptive analysis, it shows that the most student prefers IDR 750,000 reward to be paid in cash

The reward in this study has no effect on student loyalty. Where the t-statistic value is $0.711<1.99$ with a significance of $0.477>0.005$. The results of this study are not in line with the results of research (Noviandari, 2018) which states that giving reward can increase student loyalty. Thus, giving direct rewards that is done shows it is unable to increase student loyalty in joining the member get member program to increase the number of new students.

Student satisfaction in this study has significant influence to student loyalty. The results of the study are in line with (Ramadhani, 2017) which implies that giving intrinsic rewards can increase student loyalty through student satisfaction. Thus, the management and foundations at higher education institutions must have a strong commitment to give rewards, especially to students who are able to recommend studying at their campus.

\section{Conclusion}

Based on the results of the research, there are some conclusions that can be drawn 1) Rewards have a significant effect on student satisfaction at STIE Muhammadiyah Asahan. 2) Reward has no effect on student loyalty at STIE Muhammadiyah Asahan. 3) Student satisfaction has a significant effect on student loyalty at STIE Muhammadiyah Asahan.. 4) Reward has a significant effect on student loyalty through student satisfaction at STIE Muhammadiyah Asahan.

\section{References}

Adlan, R. S. M. A. (2017). Pengaruh Service Quality, Marketing Mix dan Kepuasan Mahasiswa terhadap Customer Loyalty. Jurnal Ekonomi Modernisasi, 13(1), 1-15. https://doi.org/10.21067/jem.v13i1.1567

Amelia, N. R. (2018). Pengaruh Kualitas Pelayanan, Harga Dan Citra Kampus Terhadap Loyalitas Mahasiswa Mengikuti Program MGM (Member Get Member) Melalui Kepuasan Mahasiswa Sebagai Variabel Intervening. Abdi Ilmu, 1(1), 121-133.

Anggraini, A. H. A. A. P. A. N. P. N. (2020). Pengaruh Kualitas Pelayanan, Diskon, Customer Relationship Management (Crm) Terhadap Loyalitas Konsumen Pada PT. Ramayana Lestari Sentosa Tbk. Denpasar. Jurnal Emas, 1(1), 43-66.

Fatricia, T. R. S. (2015). Pengaruh Reward Dan Sponsorship Terhadap Loyalitas Konsumen (The Influence of Rewards and Sponsorship on Customer Loyalty). Digest Marketing, 1(1), 8-14.

Griffin, J. (2010). Customer Loyalty, Menumbuhkan dan Mempertahankan Kesetiaan Pelanggan. Alih Bahasa Dwi Kartini Yahya. Jakarta: Erlangga.

Harjanto, T. A. P. C. T. (2020). Pengaruh Mutu Pembelajaran Online Dan Tingkat Kepuasan Mahasiswa Terhadap Hasil Belajar Saat Pandemi Covid19. Pendidikan Teknologi Dan Kejuruan, 17(2), 188-197.

Iriyadi, H. A. S. (2020). Evaluasi Atas Penerapan Sistem Informasi Akademik Dan Keuangan Terhadap Tingkat Kepuasan Mahasiswa. Jurnal Analisis Sistem Pendidikan Tinggi, 4(2), 137-148.

Ismanova, D. (2019). Students' Loyalty In Higher Education: The Mediating Effect Of Satisfaction, Trust, Commitment On Student Loyalty To Alma Mater. Management Science Letters, 9(8), 1161-1168. https://doi.org/10.5267/j.msl.2019.4.024 
Keller, P. K. K. L. (2012). Manajemen Pemasaran Edisi 12. Jakarta: Erlangga.

Kusumawidjaya, R. M. E. (2020). Pengaruh Gamifikasi Terhadap Loyalitas Pelanggan Jaringan Hotel Internasional di Surabaya. Fokus Bisnis: Media Pengkajian Manajemen Dan Akuntansi, 19(02), 144-153. https://doi.org/10.32639/fokusbisnis.v19i2.667

Martin, N. (2018). The Influence Of The Price Cuts And The Atmosphere Of Thte Campus Of Impulse Buying Studi In The Politeknik Unggul LP3M. In ICOES (Vol. 1, pp. 17).

Nahar, M. A. A. R. W. F. H. (2018). The Role of Religiosity , Halal Awareness , Halal Certification, and Food Ingredients on Pengaruh Program Loyalitas terhadap Purchase Intention of Halal Food Kesetiaan Konsumen pada Industri Halal Yogyakarta Pengaruh Program Loyalitas terhadap Kesetiaan. Jurnal Of Islamic Economics, Finance And Banking, 1(1), 69-88.

Nasib. (2017). Pengaruh Kualitas Pelayanan Terhadap Kepuasan Pelanggan (Studi Kasus Pada Kola Renan Bengawan Solo Pangkalan Brandan). Jurnal Ilmiah Manajemen \& Bisnis, 18(1), 30-44.

Noviandari, F. F. N. R. I. (2018). Pengaruh Point Reward, Undian Berhadiah Dan Asuransi Terhadap Loyalitas Pelangan PT. ISM Bogasari Flour Mills Surabaya. Jurnal Manajemen Branchmarck, 4(1), 168-178.

Nurjanah, S., et al. (2020). The Development of the Assurance Relevance Interest Assessment Satisfaction (Arias) Collaborative Jigsaw Collaborative Learning Model in Writing News Text Class 8 Junior High School State 06 Medan. Budapest International Research and Critics in Linguistics and Education (BirLE) Journal, 583-590.

Priyono, T. C. M. N. S. C. (2018). The Effect of Service Quality on Student Satisfaction and Student Loyalty: An Empirical Study. Journal of Social Studies Education Research, 9(3), 109-131.

Purwati, T. C. L. H. S. C. A. A. (2019). The Influence of Service Quality, University Image On Student Satisfaction And Student Loyalty. Benchmarking, 26(5), 15331549. https://doi.org/10.1108/BIJ-07-2018-0212

Ramadhani, E. K. F. R. (2017). Hubungan Persepsi Pemberian Reward Terhadap Kepuasan Kerja Dan Loyalitas Kerja Karyawan Pada Pekerja Pendatang. Journal of Applied Business Administration, 1(1), 82-94.

Rinawati, A. M. (2016). Pengaruh Kualitas Layanan Akademik Terhadap Kepuasan Mahasiswa Serta Implikasinya Pada Loyalitas Mahasiswa (Studi Pada Sekolah Tinggi Manajemen Informatika Dan Komputer Di Kota Bandung). Juranal Ekonomi, Bisnis \& Entrepreneurship, 10(2), 119-131.

Syakur, A. (2018). Hubungan Kualitas Pelayanan Terhadap Kepuasan Mahasiswa Dan Loyalitas Mahasiswa Ditinjau Dari Model Pembelajaran Di Akademi Farmasi Surabaya. Reformasi, 8(2), 100. https://doi.org/10.33366/rfr.v8i2.1091

Torii, K. S. M. A. H. (2019). The Impact of Loyalty on the Student Satisfaction In Higher Education A Structural Equation Modeling Analysis. HEED, 13(2), 82-96. https://doi.org/10.1108/HEED-01-2019-0003

Yani, R. A. S. A. (2020). Optimalisasi Membangun Brand Image Terhadap Customer Loyalty Melalui Customer Value Dan Customer Retention Sebagai Variabel Intervening. JEB (Ekonomi Bisnis), 26(1), 268-279. 